\title{
Hanna Adamiczka
}

Uniwersytet Ekonomiczny we Wrocławiu

e-mail: hanna.adamiczka@ue.wroc.pl

\section{URBAN SHRINKAGE NA DOLNYM ŚLĄSKU - TENDENCJE W WYBRANYCH MIASTACH \\ URBAN SHRINKAGE IN LOWER SILESIA - TRENDS IN SELECTED CITIES}

DOI: $10.15611 /$ pn.2017.490.03

JEL Classification: R50

Streszczenie: Kurczenie się miast (urban shrinkage) jest zjawiskiem występującym cyklicznie w historii świata. Przemiany XX i XXI w. spowodowały, że jest to problem również współczesnych czasów. Urban shrinkage to nie tylko spadek ludności; wiąże się również z problemami ekonomicznymi, społecznymi i przestrzennymi. Artykuł ma na celu przedstawienie wyników badań nad kurczeniem się dolnośląskich miast. Zastosowane metody badawcze to: analiza literatury i dokumentów, metoda dedukcji oraz proste metody statystyczne. Przeanalizowanych zostało 10 dolnośląskich miast, dobranych ze względu na liczbę ludności. Na podstawie przeprowadzanych badań można stwierdzić, że małe miasta nie borykają się z problemem kurczenia się, natomiast zjawisko to występuje w miastach średnich i dużych. Z największych miast jedynie we Wrocławiu - stolicy województwa, odnotowano wzrost ludności w ciągu ostatnich 10 lat. Prezentowane wyniki stanowią wstęp do dalszych badań.

Słowa kluczowe: urban shrinkig/shrinkage, Dolny Śląsk, demografia, miasta.

Summary: Urban shrinkage is a cyclical phenomenon in the history of the world. The changes in the $20^{\text {th }}$ and $21^{\text {st }}$ centuries made it a problem also of modern times. Urban shrinkage is not just a fall in population; it also involves economic, social and spatial problems. This article aims to present the results of research on the shrinking of Lower Silesian cities. The applied research methods are: literature and document analysis, deduction method, simple statistical methods. Ten Lower Silesian cities, selected for their population size, were analyzed. Based on the research conducted, it can be stated that small towns are not struggling with the problem of shrinking, but this phenomenon occurs in medium and large cities. Of the largest cities only in Wrocław - the capital of the voivodship - population growth has been observed in recent years. The presented results are an introduction to further research.

Keywords: urban shrinking, Lower Silesia, demography, cities. 


\section{Wstęp}

Powstanie, rozwój i upadek miast nie są zjawiskami nowymi, występują one cyklicznie w historii świata. Dotyczą one zarówno małych jednostek osadniczych, jak i wielkich „metropolii” swoich czasów (np. mongolskie Karakorum, Tikal państwa Majów czy pałace cesarzy rzymskich na Palatynie) [Trębacz 2013].

Przełom XX i XXI w. jest okresem fundamentalnych przemian społeczno-gospodarczych, instytucjonalnych oraz demograficznych. Szybki rozwój medycyny (w szczególności antykoncepcji), wydłużenie średniej długości życia oraz zmiana modelu życia, rodziny i wartości społecznych spowodowały, że zmniejsza się liczba urodzeń i zmieniają się proporcje osób $\mathrm{w}$ wieku produkcyjnym do osób $\mathrm{w}$ wieku nieprodukcyjnym, a co za tym idzie, społeczeństwo się starzeje, w związku z czym $\mathrm{w}$ miastach mieszka coraz mniej ludzi. Ponadto miasta wyludniają się z powodów związanych ze zmianami zachodzącymi w nich samych i otoczeniu - upadkiem przemysłu, zamykaniem zakładów pracy.

Liczba osób mających co najmniej 60 lat wzrasta w Unii Europejskiej o ponad $2 \mathrm{mln}$ rocznie - w przybliżeniu dwa razy szybciej niż jeszcze około trzy lata temu. Obserwowany ciągle w większości państw członkowskich Unii stosunkowo niewielki przyrost liczby ludności UE wynika z napływu imigrantów, ponieważ poziom dzietności jest znacznie niższy niż współczynnik zastępowalności pokoleń [Unia Europejska 2011, s. 15].

Długookresowy spadek liczby ludności powiązany z kryzysem lokalnej gospodarki i narastającymi problemami społecznymi nosi miano „kurczenia się miast” (urban shrinkage/shrinking). Proces ten wiąże się zwykle z negatywnymi skutkami [Hummel 2015, s. 398]:

- ekonomicznymi (są to m.in. zmniejszenie wartości nieruchomości, utrata podatników, dostarczanie mediów, komunikacji itp. na tym samym obszarze do mniejszej ilości osób, utrzymanie opuszczonych nieruchomości),

- społecznymi (są to m.in. spadek jakości życia, wzrost przestępczości, odpływ ludzi przedsiębiorczych i wykształconych, zmiana struktury społecznej),

- przestrzennymi (są to m.in. wzrost ilości pustostanów, nieregularne wyludnianie się dzielnic, zwiększenie ilości terenów zaniedbanych).

Artykuł ma na celu przedstawienie wyników badań nad kurczeniem się dolnośląskich miast. Zastosowane metody badawcze to: analiza literatury i dokumentów, metoda dedukcji oraz proste metody statystyczne. Prezentowane wyniki stanowią wstęp do szerszych badań.

\section{Urban shrinkage na Dolnym Śląsku}

W skład Dolnego Śląska wchodzi 91 miast (por. rys. 1), w tym 4 miasta na prawach powiatu (Wrocław, Legnica, Wałbrzych i Jelenia Góra). Zgodnie z danymi z Urzędu Statystycznego, w 2015 r. ich zaludnienie wynosiło od 1831 (Wleń) do 635759 
osób (Wrocław) [http://wroclaw.stat.gov.pl/dane-o-wojewodztwie/powiaty-1541/ ludnosc-816].

Mapa na rys. 1 ilustruje podział administracyjny dolnośląskich miast w 2013 r. Analizie procesu kurczenia się miast posłuży 10 jednostek wybranych pod względem liczby ludności (najsłabiej zaludnione, słabo zaludnione, średnio zaludnione oraz najbardziej zaludnione miasta na Dolnym Śląsku):

- Wleń (1831 mieszkańców) i Prusice (2239),

- Siechnice i Gryfów Śląski (po ok. 6800),

- Jawor i Kłodzko (odpowiednio: ok. 23600 i 27 600),

- miasta na prawach powiatu: Jelenia Góra (81 010), Legnica (100 886), Wa1brzych (115 453), oraz Wrocław (635 759).

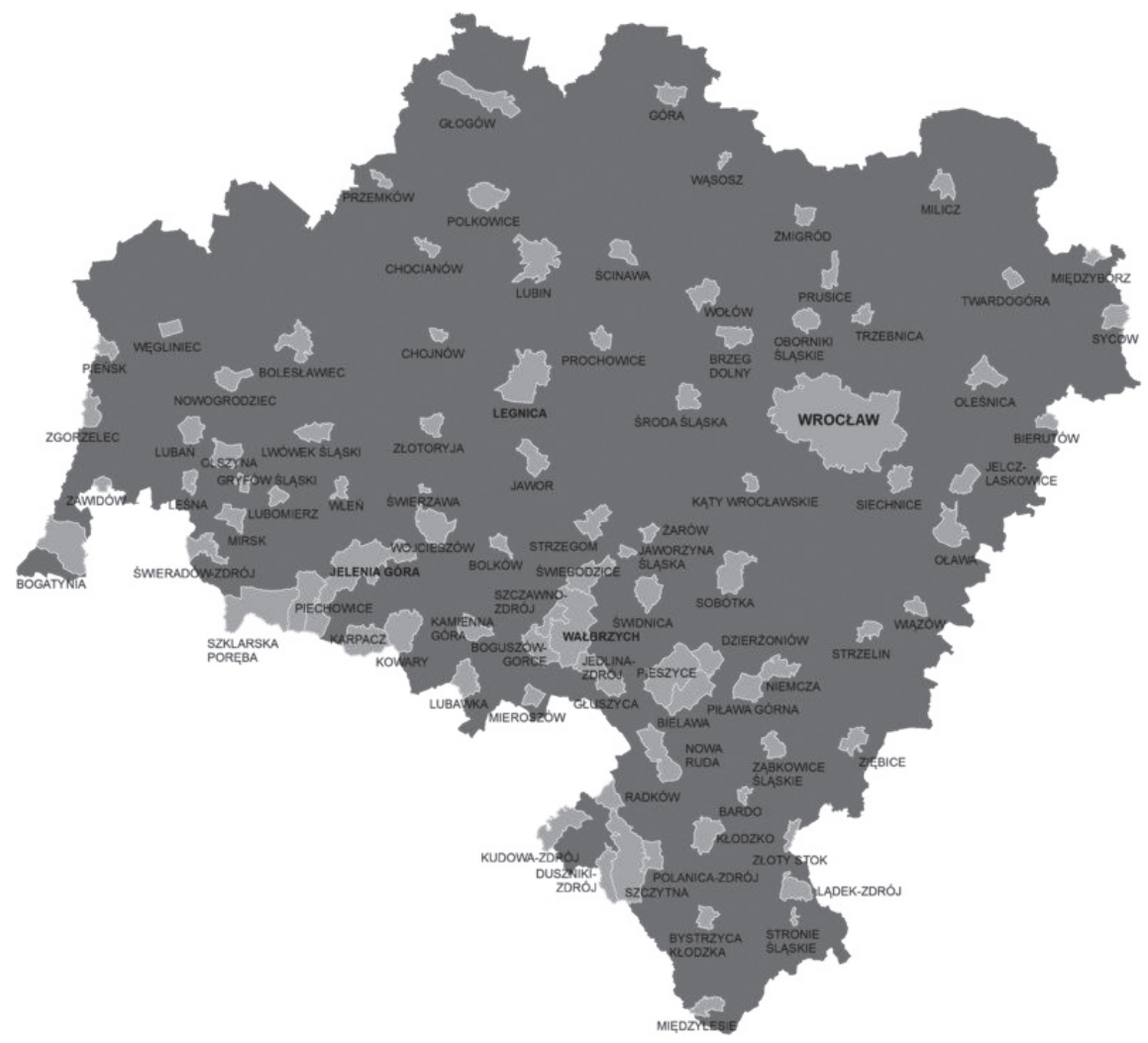

Rys. 1. Miasta województwa dolnośląskiego w 2013 roku Źródło: [www.wikimedia.org].

Proces kurczenia się miast jest definiowany przez spadek liczby mieszkańców danego miasta połączony ze negatywnymi skutkami ekonomicznymi [Stryjkiewicz (red.) 2014, s. 9]. W literaturze naukowej nie jest określone, jak duża musi być 
depopulacja, żeby móc mówić o urban shrinking. Poniżej przedstawiono analizę 10 ośrodków zurbanizowanych Dolnego Śląska. Dane analizowano od 1995 r. lub, jeśli nie było takiej możliwości, od najwcześniejszych dostępnych.

\subsection{Wleń}

Wleń jest małym miastem położonym w powiecie lwóweckim, niecałe $20 \mathrm{~km}$ od Jeleniej Góry. W 2005 r. liczba ludności wynosiła 1888, natomiast w 2016 r. - 1831. Daje to spadek o niecałe 3\% populacji w ciągu 11 lat (rys. 2).

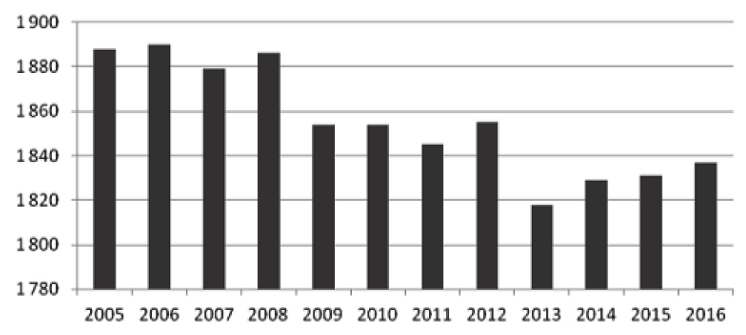

Rys. 2. Zmiany populacji we Wleniu w latach 2005-2016

Źródło: opracowanie własne na podstawie danych Banku Danych Lokalnych GUS [www.bdl.stat.gov.pl].

Dodatkowo można zauważyć dwa duże spadki ludności zanotowane między rokiem 2008 a 2009 oraz 2012 a 2013. Nie zaobserwowano stopniowej depopulacji, a w połączeniu z niewielkim spadkiem ludności, można wywnioskować, że problem kurczenia miast nie dotyczy Wlenia.

\subsection{Prusice}

Prusice to miasteczko z powiatu trzebnickiego, położone ok. $35 \mathrm{~km}$ od Wrocławia. Liczba ludności wzrosła od 2212 w 2000 r. do 2234 w 2016 r. (por. rys. 3). Najwięk-

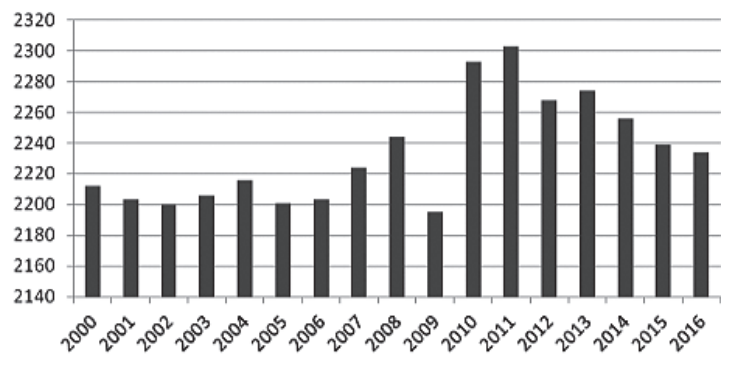

Rys. 3. Zmiany populacji w Prusicach w latach 2000-2016

Źródło: opracowanie własne na podstawie danych Banku Danych Lokalnych GUS [www.bdl.stat.gov.pl]. 
sze zmiany w liczbie ludności nastąpiły w latach 2008 i 2009 (gwałtowny spadek) i 2009 i 2010 (gwałtowny wzrost). Od 2013 r. liczba ludności systematycznie spada, jednak jest to niecałe $2 \%$ w ciągu 3 lat (rys. 3 ).

Na podstawie dostępnych danych można wywnioskować, że najmniejsze miejscowości Dolnego Śląska nie przechodzą procesu kurczenia się. W przypadku Prusic zaobserwowano wręcz nieznaczny wzrost populacji (niecały $1 \% \mathrm{w}$ ciągu 16 lat).

\subsection{Siechnice}

Siechnice są niewielkim miastem położonym $\mathrm{w}$ powiecie wrocławskim, oddalone $12 \mathrm{~km}$ od Wrocławia - stolicy województwa dolnośląskiego. Do roku 2009 r. Siechnice charakteryzowała stosunkowo stała liczba mieszkańców. W 2010 r. nastąpił dosyć gwałtowny wzrost ludności i od tego czasu populacja miasta stale wzrasta (por. rys. 4.).

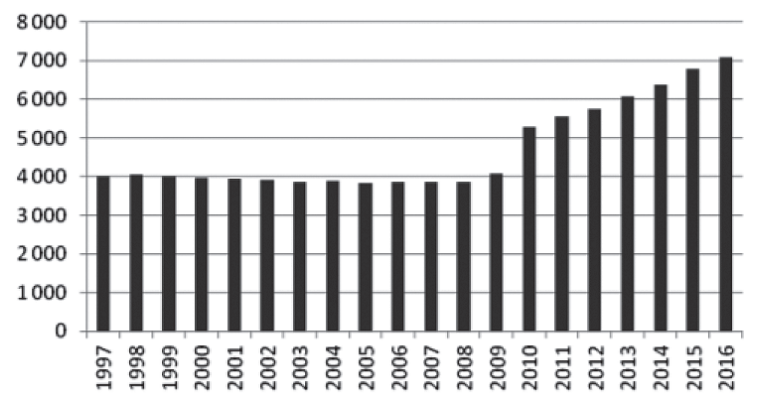

Rys. 4. Zmiany populacji w Siechnicach w latach 1997-2016

Źródło: opracowanie własne na podstawie danych Banku Danych Lokalnych GUS [www.bdl.stat.gov.pl]

W ciągu 7 lat (2009-2016) nastąpił wzrost ludności o niemal 74\% wynikający zarówno z dodatniego przyrostu naturalnego, jak i z napływu ludności. Jeżeli ten trend się zachowa, w latach 2019-2020 można spodziewać się podwojenia liczby mieszkańców w stosunku do 2009 r. Tendencja ta prawdopodobnie wynika z bliskości Wrocławia i procesu suburbanizacji [Gainsborough 2002].

\subsection{Gryfów Śląski}

Gryfów Śląski to miasto położone w gminie miejsko-wiejskiej w powiecie lwóweckim, oddalone od Jeleniej Góry o ok. $30 \mathrm{~km}$. Charakteryzuje się zdecydowaną tendencją spadkową populacji. Największy spadek zanotowano między 1998 a 1999 r. - z 7800 do 7403 mieszkańców. Następnie do 2009 r. populacja Gryfowa stopniowo się zmniejszała. Dopiero w 2010 r. nastąpiło „odbicie” i podniosła się liczba ludności z 6832 do 7100 . Po tym czasie znów notowano regularny spadek liczby mieszkańców (por. rys. 5). Między 1998 a 2016 r. liczba ta zmniejszyła 


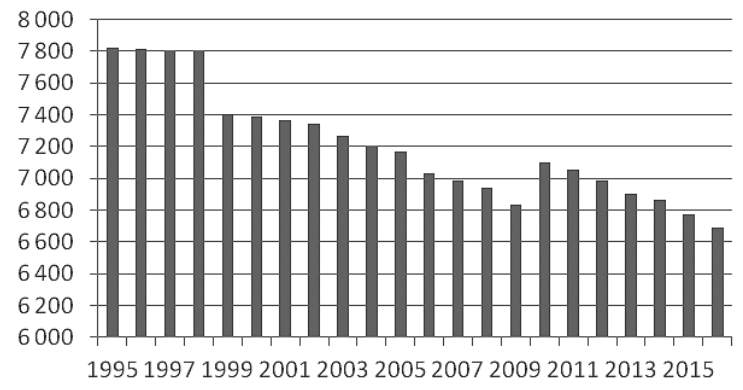

Rys. 5. Zmiany populacji w Gryfowie Śląskim w latach 1995-2016

Źródło: opracowanie własne na podstawie danych Banku Danych Lokalnych GUS [www.bdl.stat.gov.pl]

się o ponad $14 \%$. Wiąże się to zarówno z ujemnym przyrostem naturalnym, jak i niekorzystnymi migracjami. Obecnie nie ma informacji o tym, by Gryfów Śląski zmagał się z problemami ekonomiczno-społecznymi, jednak tendencja spadkowa populacji jest pierwszą przesłanką, że miasto zaczyna się kurczyć i należy przedsięwziąć odpowiednie środki, by zapobiec temu procesowi lub zamortyzować jego negatywne efekty. Niepokój może wzbudzić również zmiana struktury wieku - zaobserwowano zdecydowany spadek liczby ludności w wieku produkcyjnym i przedprodukcyjnym i wzrost liczby ludności w wieku poprodukcyjnym [www.bdl.stat.gov.pl].

\subsection{Jawor}

Jawor jest gminą miejską położoną w powiecie jaworskim, oddaloną o ok. $20 \mathrm{~km}$ od Legnicy. Sytuacja demograficzna w Jaworze (rys. 6) dokładnie odpowiada sytuacji zaobserwowanej w Gryfowie Śląskim (por. rys. 5).

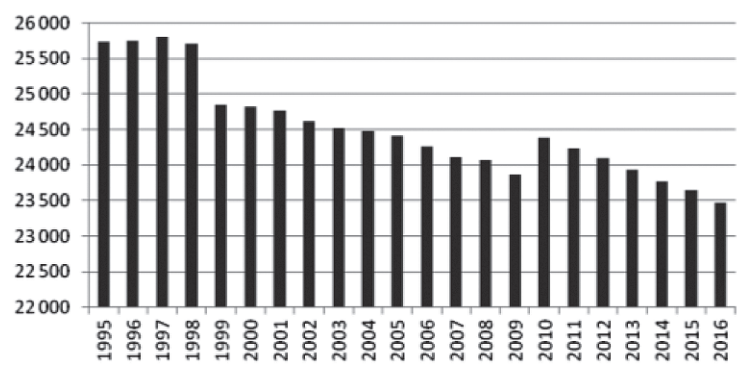

Rys. 6. Zmiany populacji w Jaworze w latach 1995-2016

Źródło: opracowanie własne na podstawie danych Banku Danych Lokalnych GUS [www.bdl.stat.gov.pl].

Do 1998 r. liczba ludności była względnie stała. Następnie zaobserwowano gwałtowny spadek i stopniową depopulację wynikającą z emigracji i ujemnego przyrostu 
naturalnego. W 2010 r. nastąpił znów wzrost liczby mieszkańców, ale potem znów odnotowywano regularny spadek. Między 1998 a 2016 r. liczba ludności spadła o prawie 7\%. Podobnie jak w Gryfowie, nie ma informacji na temat problemów gospodarczo-społecznych w Jaworze, jednak jeżeli liczba ludności będzie nadal spadać, efektem mogą być narastające problemy przestrzenne, ekonomiczne i społeczne. Zaobserwować można spadek liczby ludności w wieku produkcyjnym i przedprodukcyjnym oraz szybki wzrost liczby ludności w wieku poprodukcyjnym - społeczeństwo zaczyna się starzeć [www.bdl.stat.gov.pl].

\subsection{Kłodzko}

Kłodzko jest gminą miejską w powiecie kłodzkim. Jest oddalone od Wałbrzycha o ok. 60 km. Liczba mieszkańców Kłodzka wynosi 27 395, podczas gdy w 1995 r. było ich 30 863. W ciągu 21 lat zaludnienie spadło o 11\% (por. rys. 7), z powodu zarówno ujemnego przyrostu naturalnego, jak i negatywnego wskaźnika migracyjnego.

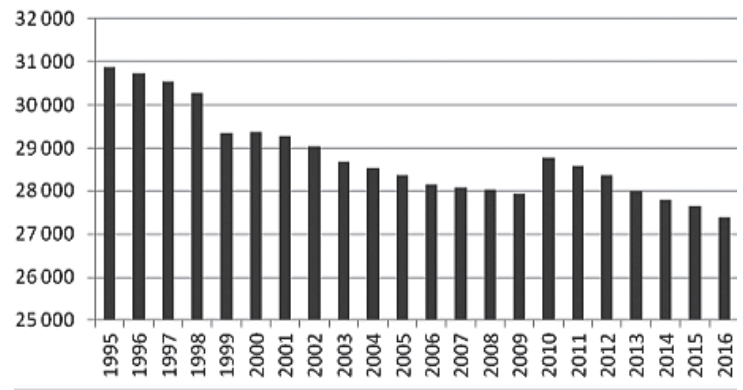

Rys. 7. Zmiany populacji w Kłodzku w latach 1995-2016

Źródło: opracowanie własne na podstawie danych Banku Danych Lokalnych GUS [www.bdl.stat.gov.pl].

Poza spadkiem populacji, w Kłodzku wzrasta stosunek liczby osób w wieku nieprodukcyjnym do liczby osób w wieku produkcyjnym - w 2013 r. wynosił 61,2:100, natomiast w 2015 r. już 65,1:100; przyrost naturalny w 2015 r. wynosił -157 [http:// stat.gov.pl/vademecum/vademecum_dolnosla-skie/portrety_gmin/powiat_klodzki/ gmina_m_klodzko.pdfl. Ponadto w ciągu ostatnich 12 miesięcy spadła cena mieszkań o średnio 31\% [https://ceny.szybko.pl/K\%C5\%82odzko-ceny-mieszkan.html]. Dobrym wskaźnikiem jest bezrobocie, które spadło z 6,48\% w 2010 r. do 4,54\% w 2016 r. [http: //pup.klodzko.pl/statystyki/tabela/date/2017-01]. W latach 90. XX w. upadło wiele przedsiębiorstw przemysłowych, ale powstała tu podstrefa Wałbrzyskiej Specjalnej Strefy Ekonomicznej, w której ulokowały kapitał duże firmy.

Na podstawie powyższych danych można wywnioskować, że Kłodzko zaczyna się kurczyć i ważne jest, by władze samorządowe podjęły kroki mające na celu zatrzymanie tego procesu lub amortyzację jego negatywnych efektów. 


\subsection{Jelenia Góra}

Jelenia Góra to najmniej zaludnione miasto z miast na prawach powiatu na Dolnym Śląsku - w 2016 r. liczyła ok. 80500 mieszkańców. Jednocześnie jest trzecia pod względem wielkości ze wszystkich miast województwa $\left(109 \mathrm{~km}^{2}\right)[\mathrm{http}: / / w r o c-$ law.stat.gov.pl/dane-o-wojewodztwie/powiaty-1541/ludnosc-816]. Liczba ludności w Jeleniej Górze stale spada od 17 lat (por. rys. 8).

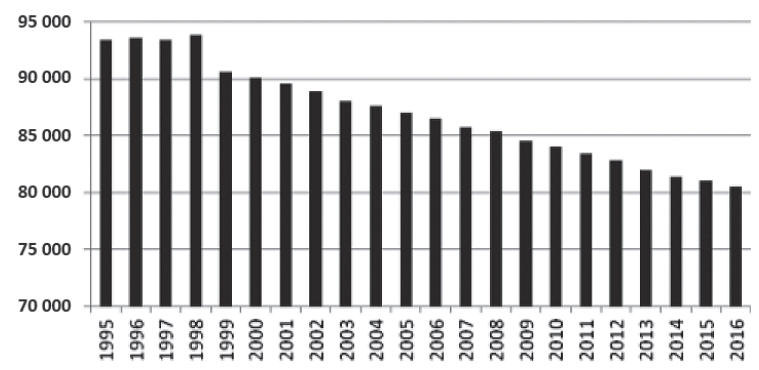

Rys. 8. Zmiany populacji w Jeleniej Górze w latach 1995-2016

Źródło: opracowanie własne na podstawie danych Banku Danych Lokalnych GUS [www.bdl.stat.gov.pl].

Między 1998 a 2016 r. populacja zmniejszyła się o ponad 14\%. Ponadto w ciągu trzech lat (2013-2015) spadł procent osób w wieku produkcyjnym (z 62,6 do 60,5\%) na korzyść osób w wieku poprodukcyjnym (wzrost z 23,1 do 25,2\%) [http://stat. gov.pl/vademecum/vademecum_dolnoslaskie/portrety_miast/miasto_Jelenia_Gora. pdf]. Spada również liczba osób fizycznych prowadzących działalność gospodarczą - w 2012 r. było ich 8388, podczas gdy w 2016 r. już tylko 7928. Podobnie jak w Kłodzku, zmniejszył się procent osób bezrobotnych [http://www.urzadpracy.jgora. $\mathrm{pl} /$ urzad_pracy/statystyki_graficzne.html].

Problem urban shrinking jest widoczny w Jeleniej Górze od kilku lat. Narastające problemy demograficzne powoli prowadzą do kłopotów ekonomicznych, a następnie społecznych. Jest to wyjątkowo niekorzystna sytuacja dla województwa dolnośląskiego, biorąc pod uwagę to, że Jelenia Góra jest jednym z czterech miast na prawach powiatu.

\subsection{Legnica}

Legnica to miasto na prawach powiatu, które ma ponad 100000 mieszkańców i jedynie $56 \mathrm{~km}^{2}$. Do $1993 \mathrm{r}$. stacjonował w niej garnizon sowiecki; dopiero po tym okresie odzyskano niemal 1/3 powierzchni miasta i zaczęto zagospodarowywać powojskowe tereny [http://zabytki.legnica.eu/historia-legnicy].

Trend demograficzny jest podobny do trendu w Jeleniej Górze. Od 1999 r. notuje się regularny spadek populacji, a liczba mieszkańców zmniejszyła się o prawie $8 \%$ w ciągu 8 lat (rys. 9). 


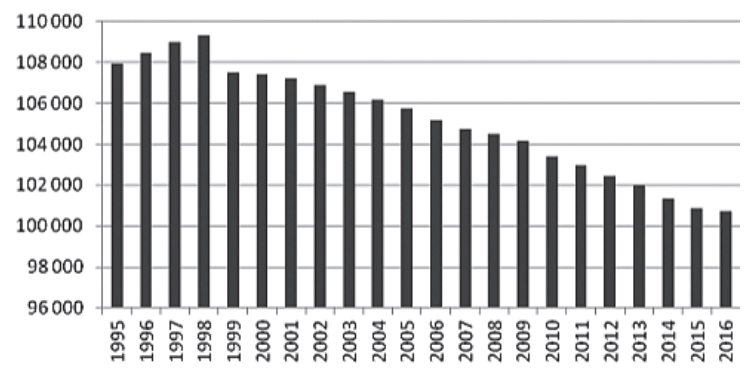

Rys. 9. Zmiany populacji w Legnicy w latach 1995-2016

Źródło: opracowanie własne na podstawie danych Banku Danych Lokalnych GUS [www.bdl.stat.gov.pl].

Między 2013 a 2015 r. procent ludności w wieku produkcyjnym spadł (z 64,1 do $62,4 \%$ ) na rzecz ludności w wieku poprodukcyjnym (z 19,6 do 21,4\%) [http://stat. gov.pl/vademecum/vademecum_dolnoslaskie/portrety_miast/miasto_Legnica.pdf]. Spadła również liczba przedsiębiorców (osób fizycznych) z 9085 (2012 r.) do 8759 (2016 r.). Procent bezrobocia spadł z 6,28 w 2003 r. do 1,53 w 2016 r. [www.bdl.stat. gov.pl]. Legnica jest kolejnym z dużych miast, które stopniowo się kurczy.

\subsection{Wałbrzych}

Wałbrzych jest dolnośląskim miastem na prawach powiatu o powierzchni $85 \mathrm{~km}^{2}$ i zaludnieniu 114 568, co daje mu czwarte miejsce w województwie pod względem wielkości i drugie pod względem populacji. W 2003 r. Wałbrzych utracił prawa powiatu na 10 lat [www.bdl.stat.gov.pl].

Wałbrzych jest miastem poprzemysłowym - do 1989 r. rozwijane były przemysł ciężki związany z górnictwem oraz wydobycie węgla kamiennego. Obecnie miasto słynie z produkcji porcelany - trzy duże fabryki spowodowały, że miasto stało się pierwszym ośrodkiem produkcji porcelany w kraju [http://poznaj.um.walbrzych.pl/ $\mathrm{pl} /$ page/historia].

Liczba ludności w Wałbrzychu stale nieznacznie spada. Między 1995 a 2016 r. populacja zmniejszyła się o niemal 18\%, co daje ponad 24600 osób mniej (rys. 10). Podobnie jak $w$ innych miastach, również Wałbrzych notuje zmianę udziału ludności w wieku produkcyjnym ( spadek z 63,4\% w 2013 r. do $61,8 \%$ w 2015 r.) oraz wzrost udziału osób w wieku poprodukcyjnym (z 21,9\% w 2013 r. do 23,6\% w 2015 r.) [http://stat.gov.pl/vademecum/vademecum_dolnoslaskie/portrety_miast/ miasto_Walbrzych.pdf]. Miasto boryka się również z problemami ekonomicznymi - dwie z trzech fabryk porcelany obecnie są w stanie upadku. Zakład „Książ” został rozebrany w 2013 r. [https://dolny-slask.org.p1/525789, Walbrzych,Fabryka_Porcelany_Ksiaz_nieistniejaca.html], a „Wałbrzych S.A.” został odkupiony od syndyka w $2011 \mathrm{r}$. i rok później ostatecznie zamknięty [http://www.gazetawroclawska.pl/ artykul/9088464,fabryka-porcelany-walbrzych-w-ruinie-byly-zaklad-pod-lupe-wzie 
la-policja,id,t.html]. Liczba osób fizycznych prowadzących działalność gospodarczą spadła przez cztery lata o 536 przedsiębiorców; jedynie procent bezrobotnych spadł z 11,1\% w 2003 r. do 3,4\% w 2016 r. [www.bdl.stat.gov.pl].

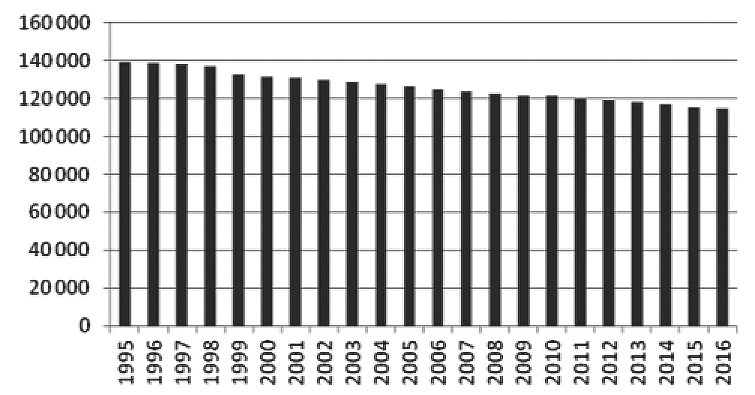

Rys. 10. Zmiany populacji w Wałbrzychu w latach 1995-2016

Źródło: opracowanie własne na podstawie danych Banku Danych Lokalnych GUS [www.bdl.stat.gov.pl].

Powyższe dane wskazują, że Wałbrzych jest miastem silnie kurczącym się. Zmiany demograficzne nie są gwałtowne, ale regularne; ponadto następują problemy ekonomiczne, które należy amortyzować. Interwencja władz samorządowych powinna być zdecydowana i szybka.

\subsection{Wroclaw}

Wrocław jest stolicą Dolnego Śląska i jego największym, najbardziej zaludnionym miastem. Jego powierzchnia wynosi 293 km²; w 2016 r. zamieszkiwały go 637683 osoby, a liczba ta stale rośnie (por. rys. 11).

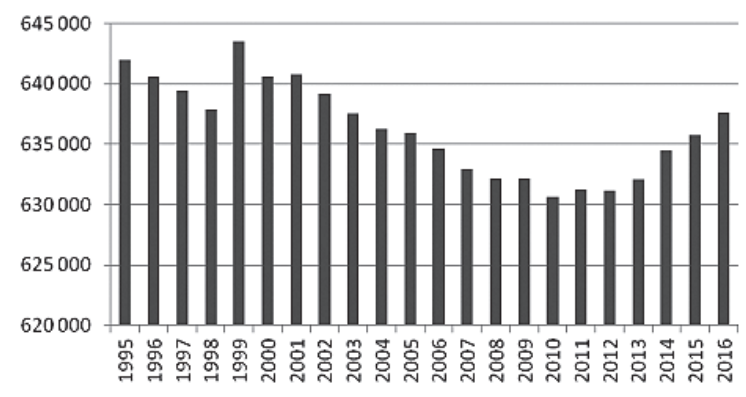

Rys. 11. Zmiany populacji we Wrocławiu w latach 1995-2016

Źródło: opracowanie własne na podstawie danych Banku Danych Lokalnych GUS [www.bdl.stat.gov.pl].

Zgodnie z danymi z Banku Danych Lokalnych, najwięcej osób zamieszkiwało Wrocław w 2009 r. - 632146 mieszkańców. Później notowano regularny spadek 
do 2011 r., w którym nastąpił przełom i liczba ludności ponownie zaczęła wzrastać. W przeszłości Wrocławiowi groziło kurczenie się, jednak obecnie nie ma tego problemu.

\section{Zakończenie}

Urban shrinkage, czyli kurczenie się miast, jest procesem znanym z historii. Miasta się wyludniały i zostawały jedynie budynki; dotyczyło to zarówno małych osad, jak i „metropolii” swoich czasów. Obecnie wiele miast na świecie styka się z problemem zanikania. Jest to widoczne również na Dolnym Śląsku, szczególnie w większych miastach. Depopulacja i niekorzystna zmiana stosunku liczby mieszkańców $\mathrm{w}$ wieku produkcyjnym do liczby mieszkańców w wieku poprodukcyjnym prowadzą do problemów ekonomicznych, społecznych i przestrzennych. Na podstawie analiz demograficznych oraz ekonomicznych, można wywnioskować, że największy problem kurczenia się występuje w miastach średnich i dużych - Kłodzko, Jelenia Góra, Legnica i Wałbrzych borykają się ze spadającą liczbą ludności, zmianą struktury piramidy wieku oraz narastającymi problemami ekonomicznymi. Mniejsze miasta, takie jak Jawor czy Gryfów Śląski, zaczynają przechodzić przez omawiany proces - notuje się spadek ludności, jednak jeszcze nie ma powiązań z problemami ekonomicznymi. Najmniejsze miasta oraz stolica województwa nie notują zmniejszenia liczby ludności. Powyższe analizy są jedynie wstępem do dalszych, szerszych badań nad problemem kurczenia się dolnośląskich miast.

Obserwacja zmian demograficznych, ekonomicznych, społecznych i przestrzennych jest niezwykle istotna dla zarządców miast. Urban shrinking jest problemem, który można odwrócić lub zahamować jego negatywne efekty poprzez stosowanie różnego rodzaju interwencji [Damurski 2016]. Aby skutecznie walczyć z tym procesem, należy mieć świadomość, że on stopniowo narasta i zawczasu należy się do niego przygotować, również poprzez uwzględnienie go w strategiach rozwoju miast i gmin.

\section{Literatura}

Damurski Ł., 2016, Wzrost atrakcyjności przestrzeni i jakości usług publicznych jako metoda przeciwdziałania wyludnianiu się miast, materiały z seminarium Sytuacja demograficzna Wrocławia - stan i perspektywy, 22.05.2016, Wrocław, https://www.wroclaw.pl/files/rozmawia/seminarium-demografia/damurski_wzrost-atrakcyjnosci_2015_05_22_korekta.pdf (6.07.2017).

Gainsborough J.F., 2002, Slow growth and urban sprawl: Support for a new regional agenda?, Urban Affairs Review, vol. 37, no. 5, s. 728-744.

Hummel D., 2015, Right-sizing cities in the United States: Defining its strategies, Journal of Urban Affairs, vol. 37, no. 4, s. 397-409.

Stryjkiewicz T. (red.), 2014, Kurczenie się miast w Europie Środkowo-Wschodniej, Bogucki Wydawnictwo Naukowe, Poznań.

Trębacz P., 2013, Kurczenie się miasta na przykładzie Detroit, Teka Kom. Arch. Urb. Stud. Krajobr. OL PAN, IX/3, 84. 
Unia Europejska, 2011, Miasta przyszłości. Wyzwania, wizje, perspektywy, Polityka Regionalna, http:// ec.europa.eu/regional_policy/sources/docge-ner/studies/pdf/citiesoftomorrow/citiesoftomorrow_ final_pl.pdf(6.07.2017).

\section{Źródła internetowe}

http://poznaj.um.walbrzych.pl/pl/page/historia (6.07.2017).

http: //pup.klodzko.pl/statystyki/tabela/date/2017-01 (6.07.2017).

http://stat.gov.pl/vademecum/vademecum_dolnoslaskie/portrety_miast/miasto_Jelenia_Gora.pdf (6.07.2017).

http://stat.gov.pl/vademecum/vademecum_dolnosla-skie/portrety_gmin/powiat_klodzki/gmina_m_ klodzko.pdf (6.07.2017).

http://stat.gov.pl/vademecum/vademecum_dolnoslaskie/portrety_miast/miasto_Legnica.pdf (6.07.2017).

http://stat.gov.pl/vademecum/vademecum_dolnoslaskie/portrety_miast/miasto_Walbrzych.pdf (6.07.2017).

http://wroclaw.stat.gov.pl/dane-o-wojewodztwie/powiaty-1541/ludnosc-816 (6.07.2017).

http://www.gazetawroclawska.pl/artykul/9088464,fabryka-porcelany-walbrzych-w-ruinie-byly-zaklad -pod-lupe-wziela-policja,id,t.html (6.07.2017).

http://www.urzadpracy.jgora.pl/urzad_pracy/statystyki_graficzne.html (6.07.2017).

http://zabytki.legnica.eu/historia-legnicy (6.07.2017).

https://ceny.szybko.pl/K\%C5\%82odzko-ceny-mieszkan.html (6.07.2017).

https://dolny-slask.org.pl/525789,Walbrzych,Fabryka_Porcelany_Ksiaz_nieistniejaca.html (6.07.2017)

www.bdl.statj.gov.pl (6.07.2017).

www.wikimedia.org (6.07.2017). 